\title{
Uji Toksisitas Akut Ekstrak Etanol Daun Notika (Archboldiodendron calosercium (Kobuski)) Terhadap Larva Artemia salina Leach dengan Menggunakan Metode Brine Shrimp Lethality Test (BSLT)
}

\author{
Nuralifah, ${ }^{* 1}$, Asriullah Jabbar ${ }^{1}$, Parawansah $^{2}$, Ria Agus Iko ${ }^{1}$ \\ ${ }^{1}$ Fakultas Farmasi Universitas Halu Oleo, Kampus Hijau Bumi Tridharma Anduonohu Kendari 93232 \\ ${ }^{2}$ Fakultas Kedokteran Universitas Halu Oleo, Kampus Hijau Bumi Tridharma Anduonohu Kendari 93232
}

\begin{abstract}
Abstrak
Daun notika merupakan tumbuhan yang berasal dari Papua, yang tumbuh di daerah perbukitan yang telah terjadi erosi.Daun notika secara empiris memiliki manfaat menyembuhkan penyakit malaria dan mempermudah proses persalinan. Penelitian ini bertujuan untuk mengetahui kandungan metabolit sekunder dari daun notika, karakterisasi simplisia daun notika dan toksisitas akut menggunakan metode BSLT terhadap larva udang Artemia salina Leach. Ekstrak daun notika diperoleh dengan menggunakan metode maserasi dengan pelarut etanol 96\%. Pengujian skrining fitokimia dilakukan dengan metode perubahan warna yang meliputi uji alkaloid, uji flavonoid, uji terpenoid, uji tannin dan uji saponin. Pengujian karakterisasi simplisia dilakukan dengan menentukan parameter spesifik yang meliputi penetapan sari larut air dan penetapan sari larut etanol sedangkan parameter non spesifik meliputi penetapan kadar air dan penetapan kadar abu. Pengujian toksisitas akut menggunakan metode Brine Shrimp Lethality Test (BSLT) dengan menggunakan larva udang Artemia salina Leach. Hasil pengujian skrining fitokimia daun notika menunjukkan hasil positif pada flavonoid, terpenoid, saponin dan tanin. Hasil pengujian karakterisasi simplisia pada daun notika adalah kadar sari larut etanol adalah 50,04\%, kadar sari larut air adalah 32,01\%, kadar air 3,99\% dan kadar abu adalah 5,11\%. Hasil pengujian toksisitas akut dari ekstrak etanol daun notika secara BSLT menunjukan bahwa daun notika tidak bersifat toksik dengan nilai $\mathrm{LC}_{50} 1024,19 \mu \mathrm{g} / \mathrm{mL}$ sehingga dapat dimanfaatkan sebagai obat tradisional.
\end{abstract}

Kata kunci: daun notika, BSLT, toksisitas akut, Artemia salina, obat tradisional

\section{Pendahuluan}

Indonesia yang beriklim tropis memiliki aneka ragam tumbuhan yang dapat digunakan sebagai bahan obat. Penggunaan obat tradisional secara umum dinilai lebih aman dari pada penggunaan obat modern karena obat tradisional memiliki efek samping yang relatif lebih sedikit dari pada obat modern [11]. Penggunaan tumbuhan tradisional sebagai obat alternatif oleh masyarakat memerlukan penelitian lebih lanjut agar penggunaannya dapat dipertanggung jawabkan khasiat, keamanan dan standar kualitas [3]

Daun notika (Archboldiodendron calosercium (Kobuski)) adalah salah satu tumbuhan obat tradisional yang secara empiris digunakan oleh masyarakat Papua untuk pengobatan penyakit malaria dan mempermudah dalam proses persalinan. Daun notika merupakan tanaman baru sehingga perlu dilakukan skrining fitokimia, pengujian karakterisasi simplisia dan uji toksisitas.

Skrining fitokimia dilakukan untuk mengetahui kandungan metabolit sekunder meliputi alkaloid, flavonoid, tannin, saponin, dan terpenoid. karakterisasi simplisia dilakukan untuk memberikan gambaran awal terhadap jumlah senyawa pada daun notika yang meliputi penentuan par ameter spesifik (penetapan sari larut air dan penetapan sari larut etanol) dan non spesifik (kadar air dan kadar abu). Uji toksisitas pada ekstrak tumbuhan dilakukan untuk mengetahui tingkat keamanan suatu ekstrak. Pengujian toksisitas senyawa aktif atau bahan yang akan digunakan sebagai obat merupakan salah satu penelitian yang penting sebagai syarat uji keamanan suatu obat baru, sehingga dapat diketahui jumlah takaran yang tepat [10].

\footnotetext{
* KBK Farmakologi dan Farmasi Klinik, Fakultas Farmasi UHO Email: nuralifahapt11@gmail.com
} 
Salah satu metode awal yang sering dipakai untuk mengamati toksisitas pada tumbuhan adalah metode brine shrimp lethality test (BSLT). Metode BSLT merupakan salah satu cara yang cepat, murah dan mudah untuk toksisitas dari ekstrak tanaman dengan menggunakan hewan laut yaitu artemia salina Leach [9]. Hasil yang diperoleh dihitung sebagai nilai $\mathrm{LC}_{50}$ (letal concentration) ekstrak uji dengan menggunakan Minitab 17 [11]. Suatu ekstrak dikatakan aktif bila mempunyai nilai $\mathrm{LC}_{50} \leq 1000 \mu \mathrm{g} / \mathrm{mL}[2]$.

\section{Metode}

\subsection{Uтит}

Sampel daun notika diperoleh dari Kelurahan Madi, Kecamatan Paniai Timur, Kabupaten Paniai, Provinsi Papua. Penelitian ini dilakukan di laboratorium Farmasi Fakultas Farmasi Universitas Halu Oleo, dan Laboratorium Biologi FMIPA Universitas Halu Oleo. Determinasi dilakukan di Pusat Penelitian Biologi, LIPI, Cibinong. Penelitian ini merupakan penelitian eksperimental dengan mengukur jumlah larva A. salina yang mati $50 \%$ dari total larva uji. Kemudian dihitung nilai $\mathrm{LC}_{50}$ dengan memasukkan angka probit $(50 \%$ kematian larva uji).

\subsection{Preparasi Sampel}

Sampel dicuci di bawah air mengalir untuk menghilangkan kotoran yang melekat pada sampel, kemudian dilakukan perajangan dengan tujuan untuk mempermudah proses pengeringan. Sampel daun notika kemudian disortasi kering untuk menghilangkan pengotor yang masih tertinggal dan sampel yang mengalami kerusakan saat proses sortasi basah sehingga diperoleh simplisia kering. Setelah itu dilakukan penghalusan dengan tujuan untuk memperkecil ukuran partikel

\subsection{Karakterisasi Simplisia}

Karakterisasi simplisia bertujuan untuk menetapkan spesifikasi simplisia sehingga dapat menjamin mutu, keamanan, manfaat dan bahan baku simplisia. Syarat baku simplisia adalah dilakukan pengujian pada karakterisasi simplisia pada tanaman yang meliputi kadar sari larut etanol, kadar sari larut air, kadar air dan kadar abu [5].

\subsection{Skrining Fitokimia}

Skrining fitokimia bertujuan untuk memberikan gambaran tentang golongan senyawa yang terkandung dalam tanaman yang diteliti, antara lain alkaloid, flavonoid, saponin, terpenoid, dan tannin. Prosedur pengujian berdasarkan Harborne, 1987 [17].

\subsection{Ekstraksi}

Ekstraksi maserasi dilakukan dengan cara serbuk simplisia ditimbang $500 \mathrm{mg}$ dan direndam menggunakan pelarut etanol $96 \%$. Perbandingan jumlah sampel dan etanol yang digunakan adalah (1:10), setiap 1 gram sampel diekstraksi dengan $10 \mathrm{ml}$ etanol $96 \%$. Jadi 500 gram sampel dilarutkan dengan $5000 \mathrm{~mL}$ atau $5 \mathrm{~L}$ etanol 96\%. Maserasi dilakukan selama $3 \times 24$ jam, dimana setiap 1x24 jam residu dan filtrat harus dipisahkan dan dilakukan pergantian pelarut yang sama. Filtrat yang diperoleh kemudian diuapkan pelarutnya menggunakan Rotary Vacuum Evaporator pada suhu $50{ }^{\circ} \mathrm{C}$. Ekstrak cair yang diperoleh kemudian disimpan dalam cawan porselen yang kemudian dipekatkan menggunakan water bath pada suhu $60^{\circ} \mathrm{C}$

\subsection{Uji Toksisitas dengan metode Brine Shrimp Lethality Test (BSLT)}

Larutan induk dari ekstrak etanol daun notika dibuat sebanyak $20 \mathrm{~mL}$ dengan konsentrasi $4000 \mathrm{ppm}$. Pembuatan larutan induk yaitu dilarutkan terlebih dahulu ekstrak daun notika sebanyak $0,08 \mathrm{~g}$ dan ditambahkan DMSO sebanyak $2 \mathrm{~mL}$ dan dicukupkan sampai $20 \mathrm{~mL}$. Larva yang telah berumur 48 jam dimasukkan ke dalam gelas ukur menggunakan pipet tetes bersamaan air laut kemudian dicukupkan sampai $5 \mathrm{~mL}$. Setelah itu, dipindahkan ke dalam botol vial yang telah terisi $5 \mathrm{~mL}$ larutan ekstrak. Dengan cara yang sama dilakukan pada semua konsentrasi. Setelah 24 jam pasca penambahan ekstrak, maka dilakukan pengamatan kematian larva. Kriteria standar untuk menilai kematian larva udang adalah bila udang tidak menunjukan pergerakan selama beberapa detik observasi [12]. Total larva yang digunakan pada seluruh percobaan dengan 3 kali percobaan/replikasi adalah 210 ekor. Total kematian larva diperoleh dengan menjumlahkan kematian larva, dibagi dengan total larva yang digunakan setiap konsentrasi dan dikalikan dengan $100 \%$.

\section{Hasil dan Pembahasan}

\subsection{Preparasi Sampel}

Proses pengeringan simplisia dilakukan dengan cara dijemur dibawah sinar matahari dan ditutup dengan kain hitam agar sampel tidak terkena sinar matahari secara langsung sehingga kandungan aktif dalam simplisia tidak rusak dan juga memiliki sirkulasi udara yang baik sehingga mengoptimalkan proses pengeringan [14]. Sampel selanjutnya dihaluskan sehingga 
memperluas bidang kontak antara daun notika dengan pelarut dan mempercepat penetrasi pelarut ke dalam sel daun sehingga zat kimia yang diperoleh semakin banyak.

\subsection{Karakterisasi Simplisia}

Simplisia pada tanaman atau tumbuhan dikatakan baik jika memenuhi syarat baku simplisia yang tertera pada Depkes RI 2000 [5]. Karakteristik simplisia disajikan dalam tabel berikut.

Tabel 1. Karakteristik simplisia

\begin{tabular}{lcc}
\hline \multicolumn{1}{c}{ Jenis karakterisasi } & Hasil & Standar [5] \\
\hline Kadar sari larut etanol & $50,04 \%$ & $\geq 9,7 \%$ \\
Kadar sari larut air & $32,01 \%$ & $\geq 18 \%$ \\
Kadar air & $3,99 \%$ & $\leq 10 \%$ \\
Kadar abu & $5,11 \%$ & $\leq 7 \%$ \\
\hline
\end{tabular}

Penentuan kadar sari larut air dan etanol bertujuan untuk menunjukkan jumlah bahan-bahan yang dapat disari oleh air maupun etanol, sehingga dapat memberikan gambaran mengenai besarnya bahan-bahan yang terlarut dan bagian yang dimanfaatkan sebagai bahan obat [16]. Kadar sari larut etanol pada daun notika adalah 50,04\% dan kadar sari larut dalam air pada daun notika adalah 32,01\%, dimana keduanya memenuhi standar mutu yang disyaratkan $[5,8]$.

Penetapan kadar air bertujuan untuk mengetahui besarnya kandungan air, terkait dengan kemurnian dan kontaminasi yang mungkin terjadi sehingga dapat digunakan pada jangka waktu yang lama. Kadar air simplisia berperan dalam pertumbuhan mikroba sehingga sangat menentukan kualitas dan masa penyimpanan simplisia [16]. Berdasarkaan pengujian yang dilakukan maka diperoleh hasil kadar air ekstrak etanol daun notika sebanyak 3,99\%. Hasil ini telah sesuai dengan persyaratan kadar air, dimana kadar air tidak lebih dari 10\% [5]. Semakin tinggi kadar air maka akan lebih mudah ditumbuhi jamur dan kapang sehingga dapat menurunkan aktivitas biologis simplisia dalam masa penyimpanan [13].

Penetapan kadar abu dilakukan untuk memberikan gambaran kandungan mineral internal dan eksternal yang berasal dari proses awal sampai akhir. Selain itu juga dapat menggambarkan jumlah kandungan logam dalam ekstrak [16]. Kadar abu yang diperoleh dalam pengujian ini sebesar $5,11 \%$ dan memenuhi standar mutu dibawah 7\% [5].

\subsection{Ekstraksi}

Ekstraksi adalah proses pemisahan kandungan senyawa kimia dari jaringan tumbuhan maupun hewan dengan menggunakan penyari yang sesuai [5]. Proses ekstraksi yang digunakan adalah metode maserasi.
Metode maserasi merupakan cara ekstraksi yang paling sederhana dan dalam tahapanya tidak dilakukan proses pemanasan sehingga menghindari kerusakan dari senyawa yang dikandung oleh simplisisa [1]. Pelarut yang digunakan dalam penelitian ini adalah etanol $96 \%$. Etanol 96\% adalah pelarut semi polar dan pelarut yang baik untuk ekstraksi karena dapat mengekstrak senyawa yang polar dan senyawa yang non-polar. Pelarut etanol 96\% relatif kurang toksik dibandingkan metanol, murah, mudah didapat dan ekstrak yang diperoleh tidak mudah ditumbuhi jamur dan bakteri serta umum digunakan dalam pembuatan ekstrak. Selain itu, etanol merupakan pelarut yang tidak karsinogen, dan mudah menguap dengan titik didih $78^{\circ} \mathrm{C}$ sehingga tidak meninggalkan residu yang tinggi. Pelarut etanol juga merupakan pelarut dengan daya ekstraktif terbesar untuk semua bahan alam berbobot molekul rendah seperti alkaloid, saponin dan flavonoid [6].

Tabel 2. Data rendemen daun notika

\begin{tabular}{|c|c|c|c|c|}
\hline \multicolumn{3}{|c|}{ Bobot simplisia } & \multirow{2}{*}{ Bobot ekstrak } & \multirow{2}{*}{ Rendemen } \\
\hline Basah & Kering & Serbuk & & \\
\hline $6,1 \mathrm{~kg}$ & $5,7 \mathrm{~kg}$ & $5,7 \mathrm{~kg}$ & $158,36 \mathrm{~g}$ & $2,77 \%$ \\
\hline
\end{tabular}

Rendemen merupakan kadar kandungan senyawa metabolit sekunder dalam tumbuhan daun notika yang dinyatakan dalam persen.Penetapan rendemen bertujuan untuk mengetahui jumlah kira-kira simplisia yang dibutuhkan untuk pembuatan sejumlah tertentu ekstrak kental.

\subsection{Skrining Fitokimia}

Tumbuhan umumnya mengandung senyawa aktif dalam bentuk metabolit sekunder seperti alkaloid, flavonoid, tanin, terpenoid, dan saponin. Metode skrining fitokimia dilakukan dengan melihat reaksi warna dengan menggunakan suatu pereaksi

Tabel 3. Hasil pengamatan uji skrining fitokimia ekstrak daun

\begin{tabular}{|c|c|c|c|}
\hline $\begin{array}{l}\text { Golongan } \\
\text { Senyawa }\end{array}$ & Penanda & Hasil & Ket \\
\hline Alkaloid & $\begin{array}{l}\text { Endapan coklat atau } \\
\text { merah jingga }\end{array}$ & Hitam & - \\
\hline Flavonoid & $\begin{array}{l}\text { Merah jingga atau } \\
\text { jingga }\end{array}$ & $\begin{array}{l}\text { Endapan } \\
\text { coklat muda } \\
\text { jingga }\end{array}$ & + \\
\hline Terpenoid & Perubahan warna & $\begin{array}{l}\text { Hijau } \\
\text { kehitaman }\end{array}$ & + \\
\hline Saponin & Terbentuk busa & $\begin{array}{l}\text { Terbentuk } \\
\text { busa }\end{array}$ & + \\
\hline Tanin & $\begin{array}{l}\text { Hijau unggu atau } \\
\text { kehitaman }\end{array}$ & $\begin{array}{l}\text { Hijau } \\
\text { kehitaman }\end{array}$ & + \\
\hline
\end{tabular}

Keterangan:

(-) : Tidak mengandung golongan senyawa metabolit sekunder

(+) : Mengandung golongan senyawa metabolit sekunder 


\subsection{Uji Toksisitas dengan metode Brine Shrimp Lethality Test (BSLT)}

Uji BSLT (Brine Shrimp Lethality Test) digunakan sebagai uji permulaan untuk mengetahui aktivitas dari suatu zat atau senyawa yang terkandung dalam suatu ekstrak atau isolat murni. Larva Artemia salina yang digunakan dalam pengujian adalah Artemia salina yang berumur 48 jam disebabkan karena pada larva umur 48 jam mulut dan saluran pencernaannya telah terbentuk sempurna dan larva juga memiliki peningkatan ketahanan tubuh [7]. DMSO merupakan cairan tak berwarna yang memiliki rumus molekul $\left(\mathrm{CH}_{3}\right)_{2} \mathrm{SO}$ merupakan pelarut yang dapat melarutkan senyawa polar maupun non polar.

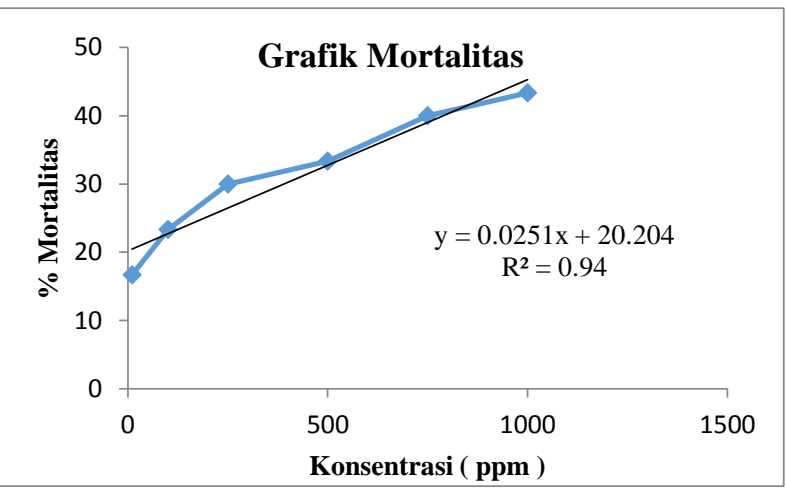

Gambar 1. Grafik mortalitas Artemia salina Leach terhadap konsentrasi ekstrak etanol daun notika

Grafik di atas menunjukan bahwa peningkatan mortalitas dari larva udang berbanding lurus dengan kenaikan konsentrasi. Tingkat mortalitas yang paling tinggi terjadi pada konsentrasi $1000 \mu \mathrm{g} / \mathrm{mL}$. Mekanisme kematian larva $A$. salina berhubungan dengan fungsi senyawa flavonoid dan saponin pada ekstrak daun notika karena senyawa flavonoid dan saponin menghambat daya makan larva (antifedant). Saponin mengandung glikosida dalam tanaman yang sifatnya menyerupai sabun dan dapat larut dalam air, flavonoid dapat menurunkan aktivitas enzim pencernaan dan penyerapan makanan [15]. Cara kerja senyawa flavonoid adalah dengan bertindak sebagai stomach poisoning atau racun perut. Oleh karena itu, bila senyawa- senyawa ini masuk ke dalam tubuh larva, alat pencernaannya akan terganggu. Senyawa ini akan menghambat reseptor perasa pada daerah mulut larva. Hal ini mengakibatkan larva gagal mendapatkan stimulus rasa sehingga tidak mampu mengenali makanannya dan akibatnya larva mati kelaparan sedangkan senyawa golongan saponin dapat mengikat oksigen yang terdapat didalam air sehingga kadar oksigen didalam air menurun dan larva Artemia salina Leach dapat mengalami kematian karena kekurangan oksigen.

Tabel 4. Hasil Pengukuran Nilai $\mathrm{LC}_{50}$

\begin{tabular}{cccc}
\hline Sampel & $\begin{array}{c}\text { Konsentrasi } \\
(\mu \mathrm{g} / \mathrm{mL})\end{array}$ & $\%$ mortalitas & $\begin{array}{c}\mathrm{LC}_{50} \\
(\mu \mathrm{g} / \mathrm{mL} / \\
\mathrm{ppm})\end{array}$ \\
\hline & 0 & & \\
Daun & 10 & 0 & 1024,19 \\
Tumbuhan & 100 & & \\
Notika & 250 & & \\
& 500 & & \\
& 750 & & \\
\hline
\end{tabular}

Berdasarkan Tabel 4, ekstrak daun notika bersifat tidak toksik terhadap larva udang Artemia salina Leach karena memiliki nilai $\mathrm{LC}_{50}=1024,19 \mathrm{ppm}$. Ekstrak dikatakan bersifat toksik jika $\mathrm{LC}_{50}<1000 \mathrm{ppm}[2]$. $\mathrm{LC}_{50}$ (Lethal Concentration 50) merupakan konsentrasi zat yang menyebabkan terjadinya kematian pada 50\% hewan percobaan yaitu larva Artemia salina Leach. Nilai $\mathrm{LC}_{50}$ menunjukan daun notika bersifat tidak toksik sehingga dapat dimanfaatkan sebagai obat tradisional.

\section{Kesimpulan}

Hasil uji karakterisasi simplisia pada daun notika adalah kadar sari larut etanol adalah 50,04\%, kadar sari larut air adalah 32,01\%, kadar air 3,99\%, kadar abu adalah $5,11 \%$. Senyawa metabolit sekunder yang terdapat dalam daun notika adalah flavonoid, terpenoid, saponin, dan tannin. Uji toksisitas akut terhadap hewan uji Artemia salina Leach memiliki nilai $L C_{50}$ sebesar 1024,19 ppm dengan interprestasi tidak toksik

\section{Daftar Pustaka}

1. Agoes G. Teknologi Bahan Alam, Bandung: Penerbit ITB, 2007.

2. Alam G. Bhrine Shrimp Lethality Test (BST) sebagai Bioassay dalam isolasi senyawa bioaktif dari Bahan Alam. Majalah Farmasi dan Farmakologi, 2002, 6(2).

3. Berna E, Juheini A, Emiyanah. Toksisitas Akut Daun Justicia gendarussa Burm. Makara Sains, 2010, 14(2).

4. Brass LJ. British Papua New Guines: Central Division, Mt Tafa, Landslip Regrowths 2400 m, Also In Herbarium, Journal of The Arnlod Arboresum, 1933, 21(2).

5. Departemen Kesehatan RI. Parameter Standar Umum Ekstrak Tumbuhan Obat, Jakarta: Direktorat Jendral POM, 2000.

6. Djamal R. Kimia Bahan Alam: Prinsip-Prinsip Dasar Isolasi dan Identifikasi, Padang: Baiturrahman, 2010.

7. Fatimawali, Adithya Y, Frenly W. Acute Toxicity Test of Etanol Extract from Mangosteen Pericarp (Garcinia mangostana L.) Against Artemia Salina Leach Larvae 
Using Brine Shrimp Lethality Test (BST), PHARMACON, 2013, 2(1).

8. Manoi F. Pengaruh Cara Pengeringan Terhadap Mutu Simplisia Sambiloto, Bul Littro, 2006, 17(1).

9. Meyer BN, Ferrigni NR, Putnam JE, Jacobsen LB, Nichols DE, McLaughlin JL. Brine shrimp: a convenient general bioassay for active plant constituents. Planta Med., 1982, 45(5);31-4.

10. Meytij JR, Joke LT. Pengujian Fitokimia dan Toksisitas Ekstrak Etanol Jantung Pisang Kepok (Musa paradisiaca LINN.) dengan Metode Brine Shrimp Lethality Test (BSLT). Jurnal Sainsmat, 2015, 4(2).

11. Risa S, Sapri, Pranamala VA. Uji Toksisitas Akut Ekstrak Etanol Akar KB (Coptosapelta tomentosa Valeton ex K. Heyne) dengan Metode Brine Shrimp Lethality Test (BSLT), Jurnal Ilmiah Manuntung, 2016, 2(2).

12. Sari LORK. Pemanfaatan Obat Tradisional Dengan Pertimbangan Manfaat dan Keamanannya. Majalah Ilmu Kefarmasian, 2006, 3(1).
13. Salim M, Sulistyaningrum N, Isnawati A, Sitorus H, Yahya, Ni'mah T. Karakterisasi Simplisia dan Ekstrak Kulit Buah Duku (Lansium domesticum Corr) Dari Provinsi Sumatera Selatan dan Jambi, Jurnal Kefarmasian Indonesia, 2016, 6(2).

14. Utomo AD, Rahayu WS, Dhiani BA. Pengaruh Beberapa Metode Pengeringan Terhadap Kadar Flavonoid Total Herba Sambiloto (Andrographis paniculata), Pharmacy, 2009, 6(1).

15. Yunita EA. Pengaruh Ekstrak Daun Teklan (Eupatorium rioarium) Terhadap Mortilitas dan Perkembangan Larva Aedes aegypti, Bioma, 2009, 11(1).

16. Zulharmitta, Kasypiah U, Rivai H. Pembuatan dan Karakterisasi Ekstrak Kering Daun Jambu Biji (Psidium guajava L.). Jurnal Farmasi Higea, 2012, 4(2).

17. Harborne JB. Metode Fitokimia: Penuntun Cara Modern Menganalisis Tumbuhan. Terjemahan Padmawinata K dan Soediro I. Bandung: Penerbit ITB, 1987. 